\title{
PENGARUH MEDIA LEAFLET TENTANG PERSONAL HYGIENE GENITALIA PADA SAAT MENSTRUASI TERHADAP PENGETAHUAN DAN PERILAKU REMAJA
}

\section{THE INFLUENCE OF THE LEAFLET MEDIA TOWARDS PERSONAL HYGIENE GENITALIA MENSTRUATION OF ADOLESCENTS KNOWLEDGE AND BEHAVIOR}

\author{
Erlinawati Dewi Hartoyo*, Bela Novita Amaris Susanto \\ Program S1 Keperawatan, STIKes YATSI Tangerang, \\ Jl. Aria Santika No.40A 15113 Kota Tangerang, Banten, Indonesia \\ *email : erlinawatidewihartoyo@gmail.com
}

\begin{abstract}
Knowledge and behavior affect the personal hygiene of young women, young women who have bad knowledge and behavior related to hygiene during menstruation can harm the reproductive organs, one of the impacts that can arise is vaginal infection due to microorganisms. The importance of providing health education is to improve adolescent knowledge and behavior related to personal hygiene. The purpose of this study was to determine the effect of health education on personal hygiene external genitalia during menstruation on adolescent knowledge and behavior. This type of research uses a preexperimental research design and a one-group pretest-posttest design research design. The analytical test used is the Wilcoxon test. The sample of this study a total of 104 respondents were taken by purposive sampling technique. The research was conducted on 3 - 13 June 2020 at the Al-Qur'an Insan Pratama Islamic Boarding School. The results of the study found that there was an effect of health education on personal external genital hygiene during menstruation on the knowledge and behavior of adolescents at the Al-Qur'an Insan Pratama Islamic Boarding School in 2020 ( $p<0.001$ ). Special attention is needed to provide health education both within the school and community levels.
\end{abstract}

Keywords: Leaflet, genitalia hygiene personal, menstruation, young women, knowledge, behavior

\begin{abstract}
Abstrak
Pengetahuan dan perilaku berpengaruh pada personal hygiene remaja putri, remaja putri yang memiliki pengetahuan dan perilaku yang tidak baik terkait hygiene saat menstruasi dapat membahayakan organ reproduksi, salah satu dampak yang bisa timbul yaitu infeksi vagina karena mikroorganisme. Pentingnya pemberian pendidikan kesehatan yaitu untuk meningkatkan pengetahuan dan perilaku remaja terkait personal hygiene. Tujuan dari penelitian ini yaitu untuk mengetahui pengaruh pendidikan kesehatan tentang kebersihan personal hygiene genetalia eksternal pada saat menstruasi terhadap pengetahuan dan perilaku remaja. Jenis penelitian ini menggunakan desain penelitian Pre-Eksperiment Design dan rancangan penelitian One Grup Pretest-Posttest Design. Uji analisis yang digunakan adalah uji Wilcoxon. Sampel dari penelitian ini sejumal 104 responden diambil dengan teknik Purposive Sampling. Penelitian dilakukan pada 3 - 13 Juni 2020 di Pondok Pesantren Al-Qur'an Insan Pratama. Hasil penelitian didapatkan ada pengaruh pendidikan kesehatan tentang kebersihan personal hygiene genitalia eksternal pada saat menstruasi terhadap pengetahuan dan perilaku remaja di Pondok Pesantren AlQur'an Insan Pratama tahun 2020 (p 0,000). Untuk itu diperlukan perhatikan khusus untuk menyediakan pendidikan kesehatan baik di lingkup sekolah maupun masyarakat.
\end{abstract}

Kata Kunci: Leaflet, personal hygiene genitalia, menstruasi, remaja putri, pengetahuan, perilaku 


\section{PENDAHULUAN}

Pubertas merupakan masa yang sedang dialami remaja yaitu seorang perempuan mengalami berbagai perubahan fisik seperti mengalami pembesaran payudara dan tumbuh rambut di sekitar pubis, mampu mengalami konsepsi yaitu menarche atau haid pertama pada perempuan. Pada masa remaja akan mengalami berbagai perkembangan seksual seperti kematangan organ seksual mulai berfungsi. Masa pubertas pada perempuan dimulai pada umur 12-18 tahun dan menstruasi pertama pada remaja disebut menarche (Noriani \& Nurtini, 2018).

Menarche merupakan perdarahan pertama dari uterus yang terjadi pada seorang wanita dan merupakan suatu puncak dari beberapa perubahan seorang wanita yang baru saja menginjak dewasa. Jumlah penduduk remaja putri di Kabupaten Tangerang yang berusia 1014 tahun berjumlah 48,9\% dan usia 15-19 tahun berjumlah 49\% (Badan Pusat Statistik, 2019). Terdapat 15 dari 20 remaja putri pernah mengalami keputihan di setiap tahunnya. Infeksi tersebut dapat disebabkan karena kurangnya kebersihan diri pada saat menstruasi terutama di daerah vagina dan memperkirakan angka kejadian infeksi saluran reproduksi (ISR) tertinggi di dunia adalah pada usia remaja (35\%$42 \%)$, dewasa muda (27\%-33\%), angka prevalensi candidiasis (25\%-50\%), bacterialvaginosis (20\%-40\%) dan trichomoniasis (5\%-15\%) (World Health Organization, 2016).

Negara Indonesia memiliki iklim panas dan lembap, sehingga perempuan di Indonesia lebih rentan mengalami ISR, berdasarkan data statistik di Indonesia tahun 2012 dari 43,3 juta jiwa remaja putri di Indonesia yang berusia 10-14 tahun berperilaku hygiene yang buruk (Rohidah \& Nurmaliza, 2019). Prevalensi ISK di Indonesia karena hygiene yang buruk masih tinggi, jumlah penderita ISK sekitar 180.000 kasus baru per tahunnya (Depkes RI, 2014).

Pendidikan kesehatan (penkes) merupakan salah satu kebijakan reproduksi pada remaja yang dilakukan melalui jalur pendidikan formal dan non formal dengan bantuan para tenaga pendidikan pada sistem pendidikan yang ada dengan strategi pembinaan kesehatan reproduksi remaja yang dilakukan melalui intervensi disekolah formal maupun non formal dan diluar sekolah dengan pendekatan pendidikan sebaya yang bertujuan untuk menambah dan meningkatkan pemahaman, pengetahuan, dan perilaku positif remaja tentang kesehatan reproduksi. Pengetahuan dan perilaku juga dapat mempengaruhi dalam melakukan personal hygiene, kemungkinan remaja putri tidak berperilaku hygiene pada saat menstruasi sehingga dapat membahayakan reproduksinya sendiri, salah satu dampak yang timbul akibat personal hygiene yang kurang yaitu timbul infeksi vagina yang di sebabkan oleh mikroorganisme (Pemiliana, 2019).

Menurut penelitian tentang Hubungan Pengetahuan dan Perilaku Personal Hygiene Pada Saat Menstruasi didapatkan hasil dari 102 responden yang memiliki perilaku baik terhadap personal hygiene saat menstruasi $29,4 \%$ dan yang memiliki perilaku buruk 70,6\% sedangkan hasil dari 102 responden yang sudah mengetahui tentang personal hygiene saat menstruasi $46,1 \%$ serta responden yang tidak mengetahui $53,9 \%$, oleh sebab itu dapat disimpulkan bahwa ada hubungan antara pengetahuan terhadap perilaku personal hygiene saat menstruasi (Setianingsih $\&$ Putri, 2017).

Pemahaman dan pengetahuan remaja akan kebersihan personal hygiene menjadi bekal untuk remaja berperan dan berperilaku serta bertanggung jawab, namun kenyataannya tidak semua remaja telah mendapatkan informasi yang benar dan cukup tentang kebersihan personal hygiene. Kebersihan reproduksi adalah komponen hygiene perorangan sebagai peran penting dalam menentukan status kesehatan seseorang khususnya terhindar dari infeksi pada alat reproduksi, sehingga penting bagi perempuan untuk menjaga kebersihan organ genitalia secara benar dan ekstra terutama pada bagian vagina saat menstruasi. Berdasarkan hasil uraian tersebut, maka peneliti tertarik untuk meneliti tentang bagaimana pengaruh pendidikan kesehatan tentang kebersihan personal hygiene genetalia eksternal pada saat menstruasi terhadap pengetahuan dan perilaku remaja.

\section{METODE PENELITIAN}

Desain penelitian ini merupakan penelitian kuantitatif dengan menggunakan desain penelitian Pre Eksperiment Design yaitu digunakan untuk mengetahui tingkat pengetahuan dan perilaku remaja dalam personal hygiene saat menstruasi, sebelum dan sesudah diberikannya (penkes) dengan menggunakan rancangan One-Group PretestPosttest Design. Penelitian dini dilakukan di 
Pondok Pesantren Al-Quran Insan Pratama. Waktu penelitian dilaksanakan pada tanggal 313 Juni 2020. Pada penelitian ini populasi yang dijadikan sebagai responden peneliti adalah remaja usia 10-15 tahun yang sudah mengalami menstruasi. Sampel dari penelitian ini diambil dengan teknik Non-Probability Sampling, yaitu Purposive Sampling dengan jumlah 104 responden. Penelitian ini menggunakan kuesioner yang terdiri dari 3 bagian yaitu data demografi, tingkat pengetahuan dan perilaku remaja. Kuesioner dibagian melalui via online sebanyak dua kali yaitu sebelum dan sesudah diberikan penkes dengan media leaflet. Setelah data terkumpul dilakukan editing, coding, processing, data entry, tabulating dan cleaning. Kemudian data dianalisis menggunakan uji statistic Wilcoxon.

\section{HASIL PENELITIAN DAN PEMBAHASAN}

Tabel 1. Frekuensi Distribusi Karakteristik

\begin{tabular}{lcc}
\hline $\begin{array}{l}\text { Karakteristik } \\
\text { Responden }\end{array}$ & Frekuensi & $\begin{array}{c}\text { Presentase } \\
(\%)\end{array}$ \\
\hline Usia & & \\
10-12 Tahun & 19 & $18,3 \%$ \\
13-15 Tahun & 85 & $81,7 \%$ \\
Kelas & & \\
VII & 56 & $53,8 \%$ \\
VIII & 48 & $46,2 \%$ \\
Agama & & \\
Islam & 104 & $100 \%$ \\
Informasi & & \\
$\begin{array}{l}\text { Personal Hygiene } \\
\text { Menstruasi }\end{array}$ & 80 & $76,9 \%$ \\
Pernah & 24 & $23,1 \%$ \\
Tidak Pernah & & \\
Sumber Informasi & Personal Hygiene \\
Menstruasi & & \\
Tidak Ada & 24 & $23,1 \%$ \\
Orang Tua & 54 & $51,9 \%$ \\
Guru & 11 & $10,6 \%$ \\
Petugas & 3 & $2,9 \%$ \\
Kesehatan & & \\
Teman & 1 & $1,0 \%$ \\
Sosial Media & 11 & $10,6 \%$ \\
\hline *sumber data: data primer & &
\end{tabular}

Berdasarkan tabel diatas dapat disimpulkan dari hasil penelitian diketahui bahwa dari 104 siswi sebagian besar berusia antara 13-15 tahun sebanyak 85 responden $(81,7 \%)$, berdasarkan kelas terbanyak yaitu kelas VII sebanyak 56 responden $(53,8 \%)$, terdapat sebanyak 104 responden beragama Islam $(100 \%)$ dan dapat dikatakan bahwa mayoritas responden beragama Islam, berdasarkan informasi personal hygiene menstruasi terdapat sebanyak 80 responden (76,9\%) pernah mendapatkan informasi dan terdapat sebanyak 24 responden $(23,1 \%)$ tidak pernah mendapat informasi, dan berdasarkan sumber informasi personal hygiene menstruasi sebagian besar terdapat dari orang tua yaitu 54 responden $(51,9 \%)$.

\section{ANALISA UNIVARIAT}

Tabel 2. Distribusi Tingkat Pengetahuan dan Perilaku Remaja Sebelum dan Sesudah Dilakukan Intervensi Pemberian Pendidikan Kesehatan

\begin{tabular}{lcl}
\hline Variabel & $\begin{array}{l}\text { Sebelum } \\
\text { Frekuensi }\end{array}$ & $\begin{array}{l}\text { Sesudah } \\
\text { Frekuensi }\end{array}$ \\
\hline $\begin{array}{l}\text { Pengetahuan } \\
\text { Baik }\end{array}$ & $54(51,9 \%)$ & $82(78,8 \%)$ \\
$\begin{array}{l}\text { Kurang } \\
\text { Perilaku }\end{array}$ & $50(48,1 \%)$ & $22(21,2 \%)$ \\
Baik & $70(67,3 \%)$ & $92(88,5 \%)$ \\
Kurang Baik & $34(32,7 \%)$ & $12(11,5 \%)$ \\
\hline *sumber data: data primer &
\end{tabular}

Berdasarkan tabel diatas diketahui bahwa dari 104 responden di Pondok Pesantren AlQur'an Insan Pratama sebelum diberikan intervensi berupa penkes personal hygiene genitalia eksternal saat menstruasi berada di kategori pengetahuan baik sebanyak 54 responden $(50,9 \%)$ dan perilaku baik sebanyak 70 responden $(67,3 \%)$. Namun setelah dilakukan intervensi berupa penkes personal hygiene genitalia eksternal saat menstruasi menunjukkan adanya perbaikan, yaitu hampir seluruh responden berada pada kategori pengetahuan baik sebanyak 82 responden $(78,8 \%)$ dan perilaku baik sebanyak 92 responden $(88,5 \%)$. Sehingga selisih yang menunjukkan perbaikan pada pengetahuan yaitu $(27,7 \%)$ dan selisih perbaikan pada perilaku yaitu $(21,2 \%)$.

\section{ANALISA BIVARIAT}

Tabel 3. Hasil Uji Normalitas Pengetahuan dan Perilaku Remaja Pre dan Post Diberikan Intervensi Pendidikan Kesehatan

\begin{tabular}{lccl}
\hline Variabel & Statistik & $\begin{array}{l}\text { Kolmo } \\
\text { grov } \\
\text { df }\end{array}$ & p-value- \\
\hline $\begin{array}{l}\text { Pengetahuan } \\
\text { Pre-Test }\end{array}$ & 0,191 & 104 & 0,000 \\
$\begin{array}{l}\text { Post-Test } \\
\text { Perilaku }\end{array}$ & 0,166 & 104 & 0,000 \\
Pre-Test & 0,198 & 104 & 0,000 \\
Post-Test & 0,182 & 104 & 0,000 \\
\hline
\end{tabular}

*sumber data: data primer 
Hasil pada tabel diatas diperoleh nilai $p$ value pada pre-test pengetahuan yaitu 0,000 , nilai $\mathrm{p}$-value pada post-test pengetahuan yaitu 0,000 , nilai $p$-value pada pre-test perilaku yaitu 0,000 dan nilai $p$-value pada post-test perilaku yaitu 0,000 . Data tersebut mempunyai hasil $p$ value $(<0,05)$ maka dapat disimpulkan bahwa data terdistribusi tidak normal. Sehingga pada penelitian ini secara bivariat menggunakan uji analisisnya adalah uji analisis Wilcoxon.

\section{UJI WILCOXON}

Tabel 4. Hasil Analisis Uji Wilcoxon Pendidikan Kesehatan Personal Hygiene Saat Menstruasi

\begin{tabular}{lcccc}
\hline & \multicolumn{2}{c}{ Pengetahuan } & \multicolumn{2}{c}{ Perilaku } \\
\hline \multicolumn{1}{c}{$\mathrm{N}$} & Pre & Post & Pre & Post \\
\hline Negatif & 104 & 104 & 104 & 104 \\
Ranks & 1 & & 0 & \\
Positif & 87 & & 69 & \\
Ranks & & & & \\
Ties & 16 & & 35 & \\
Z hitung & -8.270 & & -7.362 & \\
P hitung & 0,000 & & 0,000 & \\
\hline
\end{tabular}

*sumber data: data primer

Berdasarkan hasil tabel diatas terdapat 1 responden yang mengalami penurunan nilai pretest ke post-test (Negative Ranks) pada variabel pengetahuan dan 0 responden pada variabel perilaku. Terdapat 87 responden yang mengalami peningkatan nilai pre-test ke nilai post-test (Positive Ranks) pada variabel pengetahuan dan 69 responden pada variabel perilaku. Serta terdapat kesamaan (Ties) nilai pre-test dan post-test pada variabel pengetahuan yaitu 16 responden dan pada variabel perilaku yaitu 35 responden.

Data hasil statistik Wilcoxon didapatkan nilai p-value 0,000 ( $\mathrm{p}<0,05)$. Maka dapat disimpulkan bahwa "Ha diterima" yang artinya ada pengaruh yang signifikan antara tingkat pengetahuan dan perilaku remaja sebelum dan sesudah diberikan pendidikan kesehatan (penkes) tentang kebersihan personal hygiene genitalia eksternal terhadap pengetahuan dan perilaku remaja.

Beberapa negara berkembang masih banyak remaja yang belum mendapatkan informasi yang memadai dan belum menyadari pentingnya kebersihan diri (personal hygiene) terlebih pada saat sedang mengalami menstruasi. Hal ini mengakibatkan perilaku yang salah dan tidak sehat selama periode menstruasi mereka (Patel \& Patel, 2016).

Berdasarkan penelitian Internasional di Bangladesh menunjukkan bahwa sebelum diberikan penkes personal hygiene saat menstruasi ditemukan sebagian besar remaja memiliki praktik higienis yang buruk selama menstruasi dan dapat mempengaruhi kesehatan individu seperti terjadinya infeksi saluran kemih dan perineum. Sebagian remaja juga masih menggunakan pembalut yang tidak higienis dalam jangka waktu yang lama atau menggunakan kain berkualitas buruk, membuatnya rentan terhadap nyeri rahim. Untuk itu peneliti memberikan informasi terkait kebersihan personal hygiene pada sekelompok remaja supaya remaja dan memiliki pengetahuan dan sikap lebih baik (Haque et al., 2014).

Pendidikan mengenai kesehatan terutama sistem reproduksi, sangatlah penting untuk diperhatikan oleh setiap kalangan termasuk para orang tua maupun remaja itu sendiri. Remaja yang memiliki pengetahuan yang baik maka akan mempengaruhi sikap hingga bentuk perilaku yang baik pula untuk berusaha menjaga kebersihan genitalia. Beberapa faktor yang dapat mempengaruhi perilaku yaitu faktor internal yaitu berupa pengetahuan yang dimiliki dan faktor eksternal yang meliputi lingkungan. Jadi, dua faktor tersebut dapat mempertegas bahwa perilaku akan mengalami perubahan baik langsung maupun tidak langsung.

Berdasarkan penelitian Pengaruh Pendidikan Kesehatan Menstrual Hygiene (PMH) Terhadap Sikap Remaja Putri dalam Menjaga Kebersihan Diri Selama Menstruasi, mengatakan bahwa informasi mengenai menstruasi sering kali salah dan menyebabkan sikap negatif pada remaja putri. Selain itu, sikap juga akan berpengaruh pada perilaku remaja putri dalam menjaga kebersihan diri selama menstruasi. Masih banyak remaja yang masih mengeluhkan gatal di sekitar organ reproduksi saat menstruasi, hal tersebut dikarenakan tumbuhnya mikroorganisme yang berlebih sehingga dapat mengganggu fungsi serta menimbulkan masalah kesehatan pada organ reproduksi (Meinarisa, 2019).

Berdasarkan hasil penelitian Pendidikan Kesehatan Melalui Media, terdapat perbedaan yang bermakna pada pengetahuan responden dengan menggunakan media leaflet dimana responden dapat membaca berulang kali, isi yang lebih mudah dipahami menjadikan adanya 
perubahan pengetahuan yang juga mempengaruhi kesadaran perilaku. Proses pendidikan kesehatan dengan menggunakan media merupakan suatu cara alternatif pembelajaran untuk memenuhi kebutuhan para remaja, sehingga dapat mengoptimalkan kemampuan serta cara berpikir. Pendidikan kesehatan disini bertujuan mengubah pengetahuan serta perilaku yang kurang baik menjadi baik (Jubaedah, Entin, dyah sri yuhandini, 2019).

Remaja putri membutuhkan informasi atau pendidikan tentang proses dan kesehatan selama menstruasi, terutama sindrom pramenstruasi beserta penanganannya. Remaja putri akan mengalami kesulitan menghadapi menstruasi jika sebelumnya mereka belum pernah mengetahui atau membicarakannya baik dengan teman sebaya atau dengan ibu atau keluarga. Namun tidak selamanya ibu dapat memberikan informasi tentang menstruasi karena terhalang tradisi yang menganggap tabu untuk membicarakan tentang menstruasi, sehingga akan mempengaruhi terhadap kualitas kesehatan selama menstruasi pada remaja (Husna \& Mindarsih, 2018).

Pemberian intervensi pendidikan kesehatan personal hygiene pada saat menstruasi pada remaja dapat memberikan efek positif yang dapat meningkatkan pengetahuan serta mempengaruhi perilaku dalam menjaga kebersihan diri. Media yang digunakan dalam penyampaian pendidikan kesehatan personal hygiene saat menstruasi juga menjadi faktor pendukung yang dapat disesuaikan dan dapat digunakan guna untuk membuat peneliti menyampaikan informasi yang menarik, mudah dipahami, mudah diingat dan menyenangkan bagi remaja.

\section{KESIMPULAN DAN SARAN}

Terdapat pengaruh pendidikan kesehatan tentang kebersihan personal hygiene genitalia eksternal pada saat menstruasi terhadap pengetahuan dan perilaku remaja di Pondok Pesantren Al-Qur'an Insan Pratama yang dapat dilihat dari hasil uji statistik yaitu menunjukkan hasil uji Wilcoxon yang terdapat pada nilai $\mathrm{p}$ value dari data tersebut adalah $0,000(\mathrm{p}<0,05)$. Pentingnya pendidikan kesehatan bagi remaja terkait personal hygiene saat menstruasi, mengingat para siswi sudah mengalami menstruasi sehingga kebutuhan personal hygiene saat menstruasi harus diperhatikan dari pihak sekolah keluarga dan tenaga kesehatan.

\section{DAFTAR RUJUKAN}

1] Badan Pusat Statistik. (2019). Jumah Penduduk.

2] Departemen Kesehatan RI. (2014). Kesehatan Remaja.

3] Haque, S. E., Rahman, M., Itsuko, K., Mutahara, M., \& Sakisaka, K. (2014). The effect of a school-based educational intervention on menstrual health: An intervention study among adolescent girls in Bangladesh. BMJ Open. https://doi.org/10.1136/bmjopen-2013004607

4] Husna, F. H., \& Mindarsih, E. (2018). Pengetahuan Dan Sikap Remaja Putri Tentang Penanganan Disminorea Kelas $X$ Di Smkn 1 Depok Sleman Yogyakarta The Influence Of Health Education To Female Students 'Knowledge Level And Attitudes T Owards Dysmenorrhea Treatment In The Tenth Grade Of State Voc. 13(April), 2536.

5] Jubaedah, Entin, dyah sri yuhandini, sriyatin. (2019). Pendidikan kesehatan melalui media. 92, 30-39.

6] Meinarisa, M. (2019). Pengaruh Pendidikan Kesehatan Menstrual Hygiene (PMH) Terhadap Sikap Remaja Putri dalam Menjaga Kebersihan Diri Selama Menstruasi. Jurnal Endurance. https://doi.org/10.22216/jen.v4i1.3542

7] Noriani, M.Kes, N. K., \& Nurtini, N. M. (2018). Gambaran Perilaku Remaja Putri Terhadap Hygiene Genetalia Saat Menstruasi Pada Siswi Kelas X di SMA Negeri 5 Denpasar Tahun 2016. Jurnal Riset Kesehatan Nasional, 2(2), 188. https://doi.org/10.37294/jrkn.v2i2.119

8] Patel, H., \& Patel, R. (2016). Title of article: a cross sectional study on menstruation and menstrual hygiene among medical students of Valsad, Gujarat. International Journal of Reproduction, Contraception, Obstetrics and Gynecology. https://doi.org/10.18203/23201770.ijrcog20164331

9] Pemiliana, P. D. (2019). Perilaku Remaja Putri Dengan Personal Hygiene Saat Menstruasi Di Sma Etidlandia Medan Tahun 2018. Gaster, 17(1), 62. https://doi.org/10.30787/gaster.v17i1.341

10] Rohidah, S., \& Nurmaliza. (2019). Hubungan tingkat pengetahuan remaja putri 
51 Ikesma: Jurnal Ilmu Kesehatan Masyarakat, Vol. 17, No. 1 Maret 2021, 46-51

terhadap personal hygiene saat menstruasi di SMA Negeri 3 Pekanbaru tahun 2018. Jomis (Journal of Midwifery Science), 3(1), $32-35$.

11] Setianingsih, A., \& Putri, N. A. (2017). Hubungan Pengetahuan dan Sikap Terhadap Perilaku Personal Hygiene Mentruasi. Jurnal Ilmu Kesehatan Masyarakat, 5(4), 15-23. https://doi.org/10.33221/jikm.v5i4.15

12] World Health Organization. (2016). Kesehatan Remaja. 